DOI: $10.2478 / \mathrm{v} 10025-010-0032-7$

JOURNAL OF WATER

AND LAND DEVELOPMENT

J. Water Land Dev. No. 13a, 2009: 249-262

\title{
The response of ash-alder swamp forest to increasing stream water level caused by damming by the European beaver (Castor fiber L.)
}

\author{
Janusz CZEREPKO, Michat WRÓBEL, Andrzej BOCZON, \\ Karol SOKOEOWSKI
}

Forest Research Institute, Forest Site Science Department, Sękocin Stary, ul. Braci Leśnej 3, 05-090 Raszyn; e-mail: j.czerepko@ibles.waw.pl

\begin{abstract}
The response of an ash-alder swamp forest to water damming was studied in the Lutownia stream running in Białowieża Forest. The Łutownia stream with artificial dam existing from 2001 for small water retention purposes was the test object. The first observation of vegetation was done in 2004, when small retention construction started to influence surrounding forest, but beavers had not built their dam yet. After one year of experiments (2005) the beaver dam was constructed close to man-made dam and its influence was most significant for further studies. So, the first observation refers to the status of ash-alder swamp forest before beaver damming. Water table level was measured from the beginning of 2004. The main goal of presented studies was to determine changes of terrestrial vegetation and its habitat after increasing of the water level in the stream. One square metre plots in a frame $5 \times 5 \mathrm{~m}$ were localized in a transect close to the stream upstream and downstream artificial dam. Within 104 such plots ground vegetation (growing up to $0.5 \mathrm{~m}$ above ground) was described using Braun-Blanquet scale of abundance. The vegetation studies were conducted twice in 2004 and repeated in 2007. The list of species and their abundance were determined twice: in spring and in summer. Changes of species richness and coverage by species characteristic for floodplain and swamp forest site were evaluated. Ecological indices of soil moisture and fertility determined as the means weighed by percent cover by plant species were calculated for two periods of observation. Calculated indicator values showed that water retention increased the number of swamp forest species by 8 times, but the area of swamp habitat increased 16 times compared with 2004. The mean number of species per sample plot was the same before and after water damming by beavers. The plant association (ash-alder riparian forest) changed its floristic composition to swampier variant. Obtained results showed real impact of beavers' activity on ground vegetation and its habitat in ashalder swamp forest. Observed increased number of swamp species close to the beaver dam is positive from ecological point of view. Presented results indicate also, that species richness is strongly controlled by beaver damming. The population dynamics of beavers could also potentially affect species richness by altering the age distribution of beaver dams and abandoned ponds across the river valley landscape. Generally, this point of view could have adverse social effects because beavers' activity brings losses to forestry and agriculture. Therefore, we should try to find a balance between economy and wildlife management. Monitoring of the beaver sites should be continued to evaluate ecological consequences and to find best solution of these problems.
\end{abstract}


Key words: beaver damming, Białowieża Forest, ground vegetation changes, Łutownia stream, riparian forests, site paludification

\section{INTRODUCTION}

European beaver belonged to most common animals in our country in the Middle Ages. Due to its high "utility value" (fur, meat, musk), extensive hunting and transformation of its natural habitats led to almost complete extermination of the species in the second half of the $19^{\text {th }}$ century. In the beginning of the $20^{\text {th }}$ century the population of beavers in Poland was estimated at slightly more than 200 individuals and after the II World War - at only 130 individuals. For this reason beaver has been legally protected since 1919 . Species protection resulted in a slow increase in the population density - 500 individuals were noted in Poland in the year 1975 (http://www.wigry.win.pl/bobry/). The factor which affected beavers' population most was the programme of beaver restitution accomplished in cooperation of scientists, foresters and hunters that started in 1976. Thanks to efficient protection and reintroduction the Polish population of beavers is now estimated at 49 thousand individuals $1 / 3$ of which (14 thousand individuals) live in Podlasie Province (Leśnictwo, 2007). The main forest habitat where beavers made their dams is streams with riparian vegetation commonly named in forest typology the ash-alder swamps. Water lifted by dams creates inundations called beaver ponds. Total area of ash-alder swamps (AAS) as potential beaver sites in State Forests is estimated at c. 54 thousand hectares i.e. $0.8 \%$ of forest area (Wyniki..., 2006). The status of AAS often departs from the natural due to regulation of water relations by straightening and deepening of the stream channels and by draining their springs (CZEREPKO and WÓJCIK, 2006). The area of real sites in Poland i.e. such which preserved potential habitat conditions and adequate natural vegetation covers c. 22 thousand hectares (MATUSZKIEWICZ, 2001). On average, there are 40-50 plant species in a patch of ash-alder swamp though in Białowieża Forest as many as 72 species were noted in a relevé covering $130 \mathrm{~m}^{2}$ (SOKOŁOWSKI, 1993). Communities of AAS are particularly rich in moss and liverwort species. Moreover, ash-alder swamps are important habitats for plant and animal migrations supplementing ecological corridors of large rivers and playing soil-protection and water-protection functions. Their role was acknowledged in European law on nature protection since ash-alder swamp habitats got priority in the Appendix I to Habitat Directive (Council Directive 92/43/EEC on the Conservation of natural habitats and of wild fauna and flora).

Increasing density of beaver populations in Poland makes their activity easily visible. For the same reason, the impact of beavers on surrounding forest is also noticed. Inundation of tree stands due to dam building often results in their die-off in 2-3 years. Losses incurred by agriculture and forestry due to beavers' activity 
become more and more often a matter of social debate on economic and ecological consequences of beavers' activity and on counteractive methods. It is important to apply quantitative arguments in such a debate. Therefore, the aim of this study was to estimate ecological effects of beavers' activity (dam building) in their most preferred habitat - ash-alder swamp.

\section{STUDY OBJECT AND AREA}

Phytosociologically, ash-alder swamp habitat type in lowlands refers to the association of riparian forest (Fraxino-Alnetum W. Mat. 1952 = Circaeo-Alnetum Oberd. 1953). Hydrogenic and semi-hydrogenic soils which, depending on water level, correspond to various plant sub-communities are the substratum for ash-alder swamp forest. In habitats with relatively rapid water flow and limited bogging, communities close to ash-elm forests Ficario-Ulmetum minoris Knapp $1942 \mathrm{em}$. J. Mat. 1976 are formed. They occur on proper mud, mud-moorsh, mineral-moorsh and gley soils. Under such habitat conditions in north-eastern Poland develops subassociation Circaeo-Alnetum urticetosum Sokoł. 1980 which is characterised by a patchy occurrence of the stinging nettle in the undergrowth, by large percentage of oak-hornbeam forest species and a small coverage of alder carr species of the class Alnetea glutinosae Br.-Bl. \& R. Tx. 1943 (SOKOŁOWSKI, 1980). Moreover, the ground vegetation in the nettle sub-association is most seasonally diversified. Larger contribution of the ash tree and constant admixture of the common elm and small-leaved lime are characteristic for tree stands and the underbrush is dominated by the bird cherry. Fen soils of the peat-mud, peat-moorsh, peat-gley and peatmud-gley subtypes are formed in habitats with hampered water outflow (small terrain slope or location in the upper parts of the catchments). Sub-association Circaeo-Alnetum ranunculetosum whose vegetation refers to black-currant alder carr Ribeso nigri-Alnetum Sol.-Górn. (1975) 1987 with preserved clumpy structure and large share of swamp species of the class Alnetea glutinosae Br.-Bl. \& R. Tx. 1943 (SOKOŁOWSKI, 1980) in the undergrowth develops in such conditions.

The object of our study is situated in western part of Białowieża Forest in Forest Inspectorate Browsk, district Narewka (compartment 182C). Beaver dam is situated in the upper stretch of the Lutownia stream $5.6 \mathrm{~km}$ from its springs. Noteworthy, upper stretch of the stream (4 km downstream the springs) was regulated and now functions as a reclamation ditch. Springs of the stream are situated in a reclaimed "post alder carr" meadow.

One hundred years old alder-ash tree stand grows in the study area. Due to floods in the last 2-3 years the tree stand died on an area of 0.5 ha above the beaver dam. The habitat is represented by ash-alder swamp forest in its wet variant (AAS 1) with soil cover of partly decomposed fen underlined by poor loamy sands of glacial origin at the depth of $30-40 \mathrm{~cm}$. In the year 2001 the North Podlasian Soci- 
ety for Bird Protection (PTOP) initiated the construction of a step (the so-called rapids) lifting the water table by c. $30 \mathrm{~cm}$ (Fig. 1). After three years the study plots were set up to estimate the effect of water lifting construction on surrounding forest environment. Already in 2005 beavers settled near the step and built up a culvert under the railway $100 \mathrm{~m}$ apart from study plot. Beaver dam soon became the crucial factor in water lifting and hampering its outflow until the beginning of 2007 when beavers stopped lifting water and left the site. This study involves the status from before water lifting by beavers (with only the construction made by the PTOP, which stopped water in the stream bed only) and compares it with the situation of plant community in the first period after beavers' emigration.

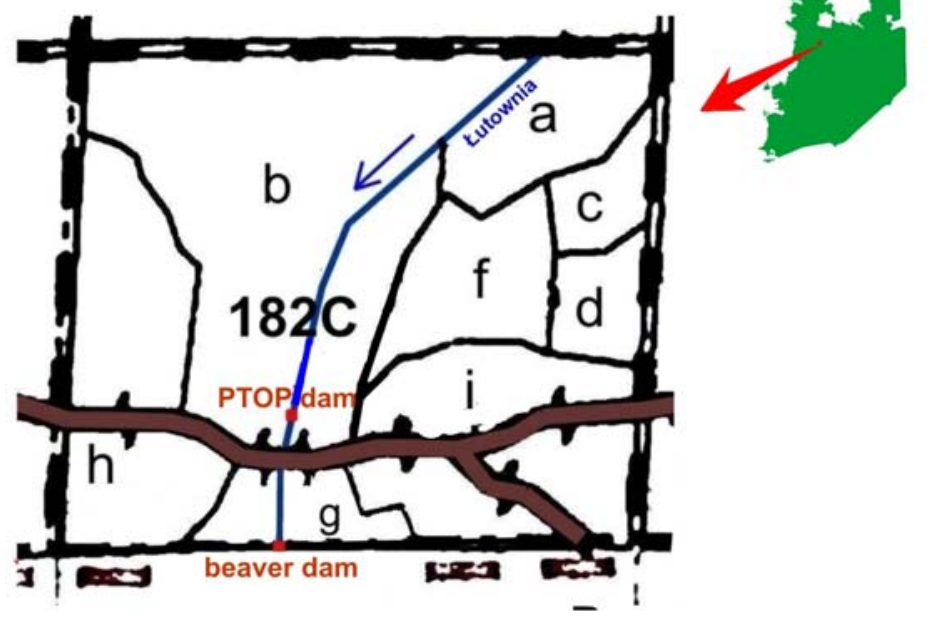

Fig. 1. Location of the study area

\section{METHODS}

In September 2004 a regular grid of squares was set up in study area (ashalder swamp forest) to describe the vegetation. Sample squares were displaced in a net $5 \times 5 \mathrm{~m}$ (Fig. 2). Each square $1 \times 1 \mathrm{~m}$ was determined with a metal frame placed in the middles of areas marked by stakes. Plots were distributed in two blocks above and below the step made by the PTOP c. $40 \mathrm{~m}$ from the stream. In total 104 plots were established with 8 plots in each of 13 rows (Fig. 2).

Ground vegetation in sample squares was described with the Braun-Blanquet (1964) method. Percent coverage by particular species was estimated with the division of plants between herb (C) and moss (D) layer. The herb layer (C) involved vascular plants including tree and shrub species not higher than $0.5 \mathrm{~m}$. Spring de- 


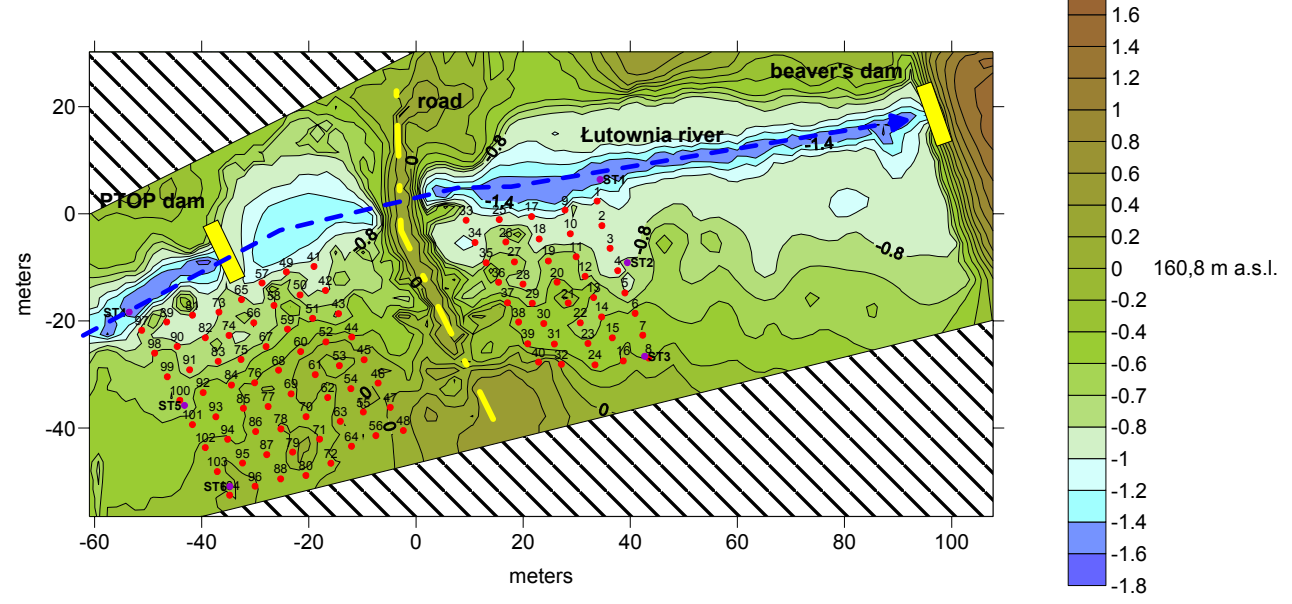

Fig. 2. Distribution of 104 sampling plots and study pipes along the Łutownia stream with terrain altitude variability

scription of ground vegetation was made with the same method in the end of April 2005. In 2007 the description of vegetation in sample squares was repeated twice, in spring and summer. Vegetation data from spring and summer were set in a table for a given year of observations where species abundance on the squares was presented as the maximum of two repetitions.

Phytosociological data obtained in field studies were used to estimate: the frequency and comparison of mean values for selected groups of ground vegetation species (with the division into riparian and alder carr species), species richness and ecological indicators acc. to ZARZYCKI et al. (2002). Applied scale of soil moisture was as follows: 1 - very dry, 2 - dry, 3 - fresh, 4 - moist, 5 - wet (bog habitats), 6 - water (aquatic habitats). Soil fertility was classified into: 1 - soils extremely poor (dry coniferous forests), 2 - poor (fresh coniferous forests), 3 - moderately poor (mesotrophic mixed forests), 4 - rich soils (eutrophic deciduous forests, low broad-leaved forests, fertile beech and riparian forests), 5 - very rich soils (extremely fertile, often fertilised). Division into alder carr and riparian species was made acc. to Matuszkiewicz (2001). Riparian species included the taxa characteristic for the alliance Alno-Ulmion Br.-Bl. \& Tx. 1943 while taxa characteristic for the class Alnetea glutinosae Br.-B1. \& R. Tx. 1943 and other of high diagnostic importance as those of the class Phragmitetea R. Tx. \& Prsg.1942, Scheuchzerio-Caricetea (Nordh. 1937) R. Tx 1937, Molinio-Arrhenatheretea R. Tx. 1937 were classified as alder carr species.

In sampling wells (see the scheme in Fig. 2) ground water table depth was measured from $1^{\text {st }}$ January 2004 till $31^{\text {st }}$ December 2007 eight times a day with the electronic limnigraph DATAFLOW SYSTEMS PTY LTD. This paper presents results of 
these measurements in study pipe no 5 from June till December in the years 2004, 2005 and 2007.

Ecological indicators values (soil moisture and fertility) were calculated as the means weighed with percentage cover of plant species. Elevations needed to make a map of terrain relief were measured with laser tachymeter Topcon.

Obtained mean values and differences were checked with Wilcoxon's test with significance estimated at $p<0.05$.

\section{RESULTS}

Measured changes of the ground water table depth in a study pipe situated 15 $\mathrm{m}$ apart from the stream characterise three periods of the impact of beaver dam on water table. Records from the year 2004 reflect the status from before building the dam. Data collected in 2005 illustrate the effect of beaver dam built in May this year (the second period). The third period started in March 2007 when beavers left the dam. Mean values of ground water table level are presented in Table 1. Before building the dam by beavers the mean water table was $159.99 \mathrm{~m}$ a.s.l. at the study pipe elevation of $160.08 \mathrm{~m}$ a.s.1. Similar value (160.02 $\mathrm{m}$ a.s.1.) was noted when beavers left the area in 2007. In the period of most intensive impact of beaver dam (the year 2005) mean water level reached the ordinate $160.19 \mathrm{~m}$ a.s.l. being higher than the levels without dam's impact by c. $20 \mathrm{~cm}$.

Table 1. Changes of the water table level in the periods June-December of the years 2004, 2005, and 2007 measured at a distance of $15 \mathrm{~m}$ from the stream

\begin{tabular}{l|c|c|c}
\hline \multirow{2}{*}{\multicolumn{1}{c}{ Level }} & \multicolumn{3}{c}{ June-December } \\
\cline { 2 - 4 } & 2004 & 2005 & 2007 \\
\hline Mean ordinate m a.s.1. & 159.99 & 160.19 & 160.02 \\
Standard deviation & 0.09 & 0.11 & 0.09 \\
\hline
\end{tabular}

Four inundations covering the area at least $15 \mathrm{~m}$ from the stream were recorded in 2004. From January till March 2005 there were 3 floods of similar range; from April till the beginning of July water remained at the ground surface. In July water level fluctuated probably due to destructions of the dam. From August till the end of the year water again remained at the ground surface. Beavers left the area in the year 2007. Till the end of March water table was still affected by the dam. Four floods occurred between June and August; later on water table dropped to the level from before beaver dam construction in 2005.

Twenty new plant species appeared after four years in the study object and 14 species disappeared. In total 102 plant species were noted on 104 plots in 2004 and 108 species in 2007. Species that disappeared included those that were frequent 
and characteristic for riparian and oak-hornbeam forests like e.g. Viola mirabilis, Melica nutans, Plagiochila asplenioides, Lapsana communis, Gagea lutea, Dryopteris filix-mas, Anemone ranunculoides. Taxa that appeared for the first time in 2007 on study plots were the species of swamp or stagnant water habitats: Callitriche cophocarpa, Riccia fluitans, Phalaris arundinacea, Carex elongata, Sium latifolium, Veronica scutellata. Mean number of species found in a sample square was 13 and did not change during the two study periods (Fig. 3).

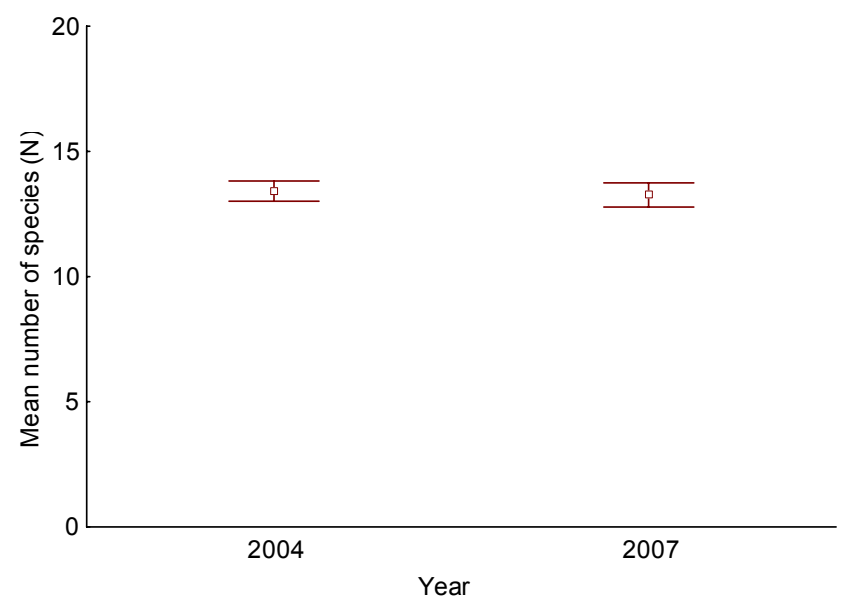

Fig. 3. Comparison of mean number $( \pm \mathrm{SE})$ of plant species on $1 \mathrm{~m}^{2}$ plots before (2004) and after (2007) beaver dam construction. The difference between mean values is not significant - Wilcoxon test at $p<0.05$

The mean index of soil moisture calculated for the whole study object from ground vegetation increased from 3.48 in 2004 to 3.93 in 2007. The frequency of sample squares with higher moisture index significantly increased (Fig. 4). If we assume the index of soil moisture $>4$ in wet, swamp and aquatic habitats (compare CZEREPKO, 2008) then the share of such areas increased fivefold from $6.7 \%$ to $35.6 \%$ and the share of bog and aquatic habitats with the soil moisture index $>4.5$ increased 16 times.

The index of soil fertility remained at the same level of 3.7 which corresponds to moderately eutrophic soils typical for ash-alder swamp forests (Fig. 5).

Marked changes took place in the area coverage by species characteristic for alder carrs (swamp forests - Ol). Initially, in 2004 mean coverage of sample squares by alder carr species was $1.5 \%$. In nearly $70 \%$ of squares no swamp species were found and in the remaining $30 \%$ the species appeared sporadically covering $0.1-5 \%$ of area (Fig. 6). Swamp species covering more than $6 \%$ of area occurred on only $5 \%$ of sampling plots. After three years the percent cover by swamp 


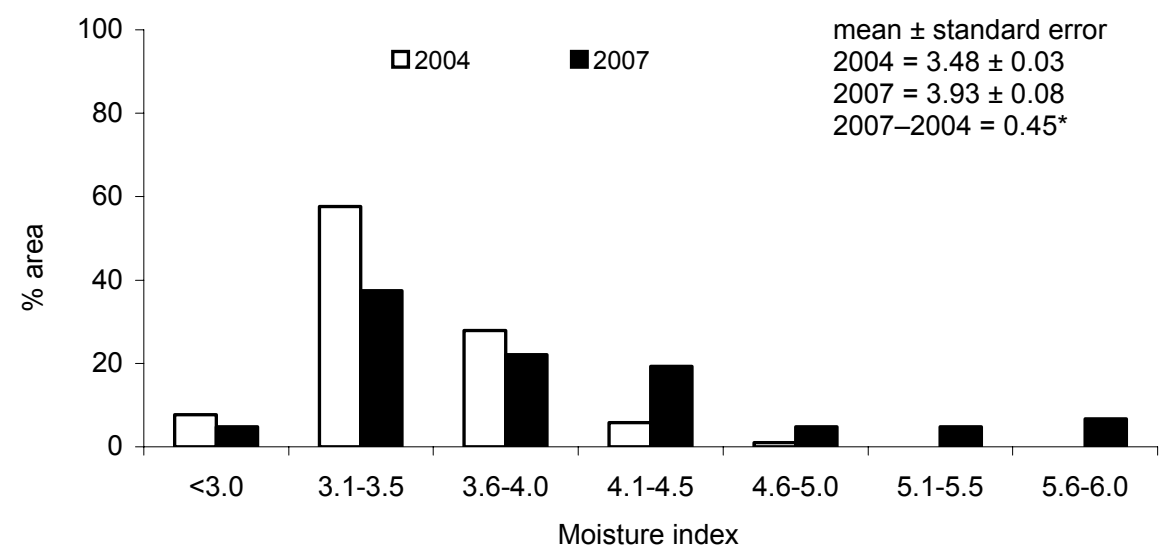

Fig. 4. Comparison of the frequency of soil moisture index on $1 \mathrm{~m}^{2}$ before (2004) and after (2007) beaver dam construction. ${ }^{*}$ The difference between mean values is significant - Wilcoxon test at $p<0.05$

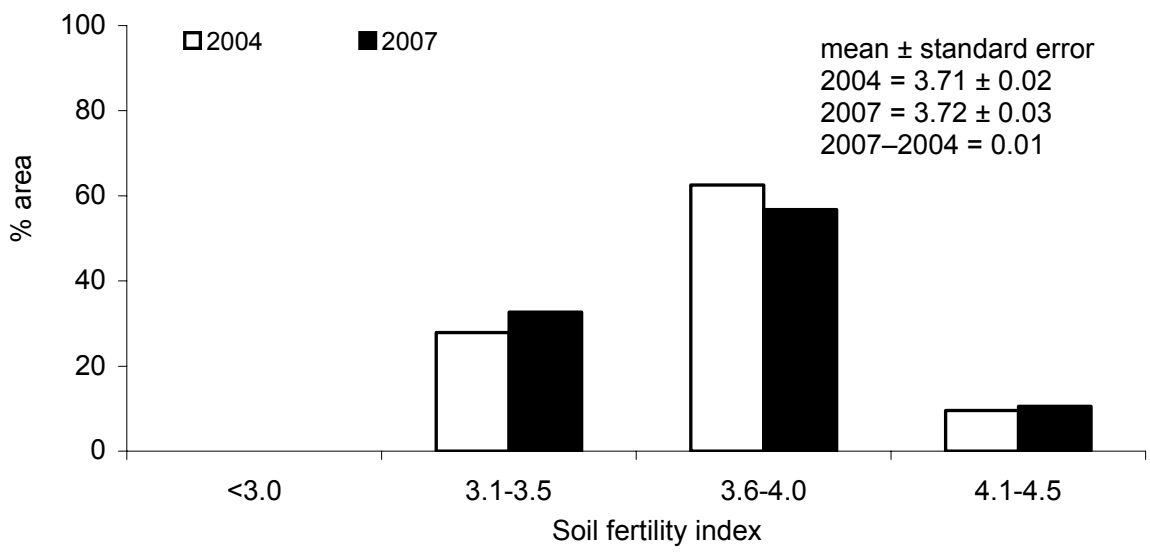

Fig. 5. Comparison of the frequency of soil fertility index on $1 \mathrm{~m}^{2}$ before (2004) and after (2007) beaver dam construction. The difference between mean values is not significant - Wilcoxon test at $p<0.05$

forest species increased 8 times. Alder carr species were noted in over half of the sampling plots. In nearly $27 \%$ of sampling plots these species showed the least coverage and in $26 \%$ of plots the coverage exceeded $6 \%$ including $10 \%$ of plots where alder carr species grew on more than half of square metre.

Species characteristic for eutrophic riparian forests decreased their share by half - from $20.6 \%$ to $10.6 \%$ (Fig. 7). Remarkable changes were observed in places where these species covered large parts of area. The number of squares where riparian species were not found increased threefold. 


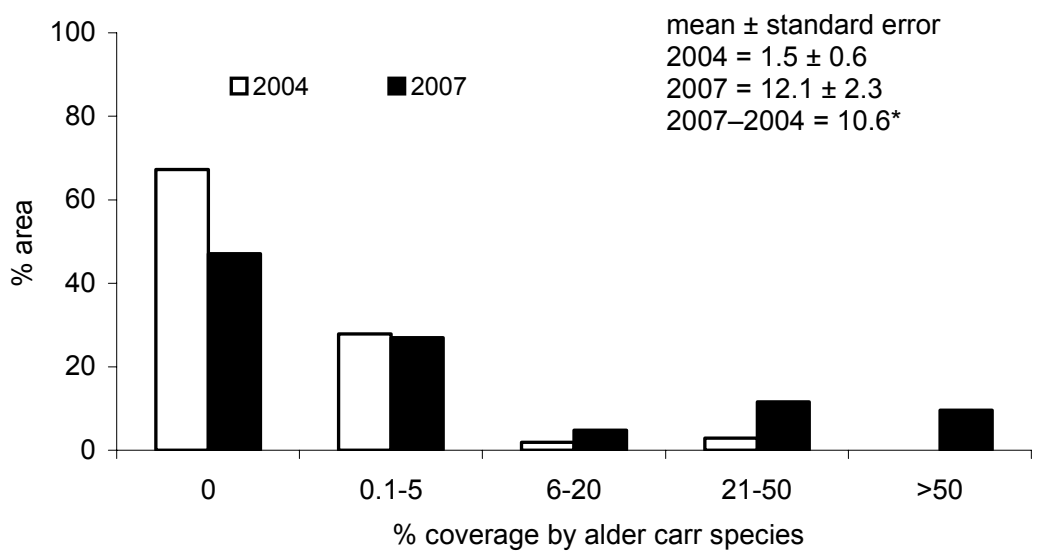

Fig. 6. Comparison of the frequency of alder carr species coverage on $1 \mathrm{~m}^{2}$ before (2004) and after (2007) beaver dam construction. * The difference between mean values is significant - Wilcoxon test at $p<0.05$

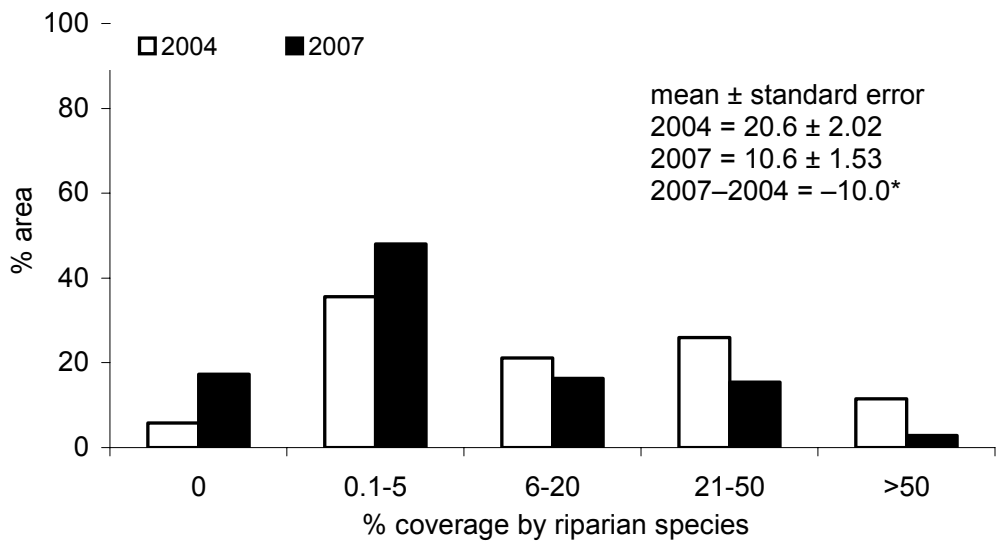

Fig. 7. Comparison of the frequency of riparian forest species on $1 \mathrm{~m}^{2}$ before (2004) and after (2007) beaver dam construction. The difference between mean values is significant - Wilcoxon test at $p<0.05$

\section{DISCUSSION}

An important factor affecting species diversity of riparian forests is the frequency and spatial variability of floods. Studies by POLLOCK et al. (1998) carried out in Alaska showed that the number of plant species increased proportionally to the number of floods achieving maximum at 11-14 floods a year and decreasing at higher frequencies. Beavers are the factor which significantly affects the frequency and spatial distribution of floods in a catchment. 
Total number of plant species observed in our studies increased by 6 species. At the same time mean number of species in a sampling plot did not change. This was a result of replacing species in riparian biotopes - swamp species replaced riparian ones while more riparian species appeared in drier places floristically similar to oak-hornbeam forests.

Interesting studies on the effect of beavers on hydrologic properties of the catchment and on water quality were initiated in North America (USA and Canada) already in the 1980's. It was found that populations of the American beaver (Castor canadensis L.) due to their food preferences and dam building may affect midforest streams by

- changing their geomorphology, hydrology and biogeochemical cycles,

- increasing organic matter sedimentation,

- enhancing the creation of wetlands,

- changing species composition and diversity of riparian vegetation,

- changing chemical properties and water quality in catchments (NAIMAN et al., 1986).

The impact of beavers in North America involves $20-40 \%$ of the total length of the 2 nd and 3rd order streams. Beaver ponds and lodges increase carbon resources in the catchment 16 times. The turnover time of carbon cycling in places inhabited by beavers increases from 24 years to 161 years. This change is evidenced by 15 -fold increase of methane emission which originates from anaerobic decomposition of organic matter stored in ponds made by beavers.

Comparative studies carried out near Lake Ontario in northern US showed that the area of beaver ponds was 47 ha in 1927 and increased to 1323 ha by 1988 (NAIMAN et al., 1994). Consequently, the content of total nitrogen increased by $72 \%$, that of phosphorus - by $43 \%$, potassium - by $20 \%$ and calcium - by $137 \%$ in horizons $\mathrm{O}$ and $\mathrm{A}$ of soils within the range of flooding caused by beavers. Organic matter and accompanying nutrients are stored in decaying plant remains and retained in flooded areas under anaerobic conditions dominating there. Large part of nutrients is incorporated into the biomass of algae and aquatic and rush vegetation associated with beaver ponds and thus recycled in a given area.

The effect of beavers on species composition in forest communities was a matter of many studies (e.g. NAIMAN et al., 1986). Beavers interfere in the course of succession in riparian forest communities by selective feeding and by changing habitat conditions due to water lifting in streams.

Stagnation of water enhances organic matter deposition on the bottom of the water body and leads to swamping of the area (NAIMAN et al., 1986) which was also demonstrated in this study. Beavers building dams significantly change the trophic status of waters and nearby terrestrial habitats. Because of lower rate of organic matter decomposition typically eutrophic species often dominant in riparian forests (like the stinging nettle, reed, reed canary grass and beggar-tick) often dis- 
appear. The fertility of habitat affected by beavers' activity often remains at the same level (as it was the case in this study) or decreases due to long-term flooding and swamping.

Due to floods caused by beavers and to their later migrations the habitat of near-shore vegetation becomes heterogeneous - single patch may include various microhabitats associated with land relief and the period of inundation. Beavers use to change the height of their dam or the dam becomes destroyed during spring floods, which together differentiates habitat conditions above and below the dam. Under such conditions the species of different ecological spectra can coexist e.g. typically swamp species may occupy long flooded hollows and riparian species may grow on elevations and in places flooded for a short time period (CZEREPKO et $a l$. ., 2006). Beavers' activity triggers off the natural fluctuation of swamp forest communities. Regulation of streams and hence their definite annual periodicity and deficit of flood waters often result in disappearance of swamp forest habitats and formation of transitory communities with the succession toward oak-hornbeam forests. Climatic changes are also important in that aspect since decreasing precipitation observed in last decades (BOCZON, 2006) have decreased the frequency of regular floods. Inhibition of water flow by beaver dams and creation of local swamping naturally restore ash-alder swamp forest habitats. Beavers' activity is thus an equivalent of human activities associated with small water retention.

Water storage in mid-forest beaver ponds positively affects avifauna (PUGACEWICZ, 2006). Increase of water temperature in beaver ponds, hampering water flow, and accumulation of organic matter in the bottom of ponds and in beavers' lodges favour the growth of invertebrates (mayflies, caddies-flies) and vertebrates (fish, amphibians, reptiles and mammals) (SNODGRASS, 1998; ROLAUFFS et al., 2001).

To sum up, the presence and activity of beavers exert positive effect on ashalder swamp forest habitat. Potential vegetation unit in the study area was ash-alder riparian forest from the swamped sub-association with the creeping buttercap Circaeo-Alnetum ranunculetosum. However, due to regulation of the stream in its upper part and drying of springs alder-ash swamps became dried up in the study area. For this reason, before beavers started to build their dam, the area was overgrown by the stinging nettle sub-association Circaeo-Alnetum urticetosum with such distinctive species like: Urtica dioica, Aegopodium podagraria (SOKOŁOWSKI, 1980). At the edges of the floodplain and on local elevations there was a transitory form of community similar to sub-continental low oak-hornbeam forests Tilio-Carpinetum Tracz. 1962. Floods from the last three years restored potential association Circaeo-Alnetum ranunculetosum.

Beavers' behaviour might be, however, considered unfavourable for forest management since flooding often causes die-off of tree stands. Therefore, final assessment of beavers' activity in forest habitats might vary depending on the standpoint of potential evaluator. 


\section{CONCLUSIONS}

Beaver dam and resulting flooding in 3 years significantly changed the species composition of plant community growing in ash-alder swamp forest habitat. Swamp species significantly increased their share as shown by both comparative analysis of soil moisture index and changes in the number of species characteristic for swamp forests. The area of swamped habitats calculated from ecological indicator values increased 16 times and the coverage by swamp species increased 8 times.

Increased coverage by swamp species was accompanied by a decrease in the number of riparian species. Studied patch of previously dried ash-alder swamp forest habitat underwent natural restitution. From ecological point of view such phenomenon should be considered the natural and positive since flooding caused by beavers restored periodical swamping of ash-alder swamp forest habitat the process not frequent in such habitats.

Studies were made within the project ordered by the National Fund for Environmental Protection and Water Management (20-U-11) and General Authority of State Forests (BLP299).

\section{REFERENCES}

1. BoczoŃ A., 2006. Charakterystyka warunków termiczno-pluwialnych w Puszczy Białowieskiej w latach 1950-2003. Leśn. Pr. Bad., 1: 57-72.

2. CZEREPKo J., WÓJCIK J., 2006. Kryteria wyróżniania oraz metody zagospodarowania siedlisk leśnych podlegających ochronie. Dokumentacja. Sękocin Stary, IBL.

3. CZEREPKo J., WróBel M., Boczoń A., 2006. Próba określenia reakcji siedliska olsu jesionowego na podniesienie poziomu wody w cieku. Leśn. Pr. Bad. 4: 7-16.

4. CZEREPKo J., 2008. A long-term study of successional dynamics in the forest wetlands. For. Ecol. Manag., 255: 630-642.

5. Council Directive 92/43/EEC on the Conservation of natural habitats and of wild fauna and flora. Dz. Urz. WE L 206/7.

6. KERSHAW K. A., 1978. Ilościowa i dynamiczna ekologia roślin. Warszawa, PWN.

7. Leśnictwo, 2007. Warszawa, GUS: 290.

8. MATUSZKIEWICZ J.M., 2001. Zespoły leśne Polski. Warszawa, PWN.

9. Naiman R.J., Melillo J.M., HobBIE J.E., 1986. Ecosystem alternation of boreal forest streams by beaver (Castor canadensis). Ecol., 67 (5): 1254-1269.

10. NAiman R.J., Pinay G., Johnston C.A., PASTOR J., 1994. Beaver influences on the long-term biogeochemical characteristics of boreal forest drainage networks. Ecol., 75 (4): 905-921.

11. Pollock M.M., Naiman R.J., Hanley T.A., 1998. Plant species richness in riparian wetlands a test of biodiversity theory. Ecol., 79(1): 94-105.

12. Rolauffs P., HeRING D., LoHSE S., 2001. Composition, invertebrate community and productivity of a beaver dam in comparison to other stream habitat types. Hydrobiol. 459: 201-212.

13. Pugacewicz E., 2006. Awifauna lęgowa doliny górnej i środkowej Łutowni. Hajnówka, maszyn. 
14. SNODGRAsS J.W., MEFFE G.K., 1998. Influence of beavers on stream fish assemblages: effects of pond age and watershed position. Ecol., 79: 928-942.

15. SокоŁowSKI A.W., 1980. Zbiorowiska leśne północno-wschodniej Polski. Monogr. Bot., 60: 205.

16. SокоŁOWSKI A.W., 1993. Fitosocjologiczna charakterystyka zbiorowisk leśnych Białowieskiego Parku Narodowego. Parki Nar. Rez. Przyr., 12.3: 5-190.

17. Wyniki aktualizacji stanu powierzchni i zasobów drzewnych w Lasach Państwowych, 2006. Warszawa, BULiGL.

\section{STRESZCZENIE}

\section{Reakcja siedliska olsu jesionowego na podniesienie poziomu zwierciadła wody w cieku w wyniku spiętrzeń powodowanych przez bobra europejskigo (Castor fiber L.)}

Słowa kluczowe: lasy tęgowe, piętrzenia powodowane przez bobry, Puszcza Biatowieska, rzeka Łutownia, zabagnienie siedliska, zmiany roślinności runa

Celem badań było określenie ekologicznych skutków działalności bobrów (budowa tam) na przykładzie najczęściej przez nich preferowanego siedliska olsu jesionowego. Obiekt niniejszych badań położony jest w zachodniej części Puszczy Białowieskiej na terenie Nadleśnictwa Browsk w obrębie Narewka (oddział 182C). Tama bobrowa występowała w górnym biegu rzeki Łutowni. Siedlisko reprezentuje ols jesionowy w wariancie dość mokrym (zespół Fraxino-Alnetum W. Mat. 1952 = Circaeo-Alnetum Oberd. 1953). Niniejsze badania obejmują stan przed piętrzeniem przez bobry (2004), gdy od trzech lat istniała tylko budowla PTOP, mająca za zadanie piętrzenie wód w korycie cieku (do $30 \mathrm{~cm}$ ), oraz porównano ze stanem zbiorowiska w pierwszym okresie po zaprzestaniu piętrzenia przez bobry (2007). Badania roślinności prowadzono na 104 kwadratach próbnych $\left(1 \mathrm{~m}^{2}\right)$ rozmieszczonych w więźbie 5 x $5 \mathrm{~m}$. Spis gatunków runa i ilościowość określano w 2004 i 2007 r. w okresie wiosny i lata. Równolegle w studzienkach badawczych wykonywano pomiar położenia zwierciadła wód gruntowych w okresie od 1.01.2004 do 31.12.2007 r. 8 razy na dobę za pomocą limnigrafów elektronicznych. W niniejszej pracy przedstawiono wyniki z pomiaru poziomu wód gruntowych $\mathrm{w}$ jednej studzience (nr 5), w okresach od czerwca do grudnia w latach 2004, 2005 i 2007.

W czasie największego oddziaływania tamy bobrowej na zwierciadło wody (rok 2005) średni poziom zwierciadła wody osiagną̧ rzędną 160,19 m n.p.m. i był wyższy od poziomów z okresów bez oddziaływania tamy o około $20 \mathrm{~cm}$. Po czterech latach na badanym obiekcie przybyło 20 gatunków roślin, a ubyło 14 . W ciagu ostatnich 4 lat nastąpił istotny wzrost wskaźnika wilgotności siedliska obliczonego na podstawie roślinności runa, którego wartość przeciętna dla całego obiektu w 2004 r. wynosiła 3,48, natomiast w 2007 r. - 3,93. Duże zmiany nastapiły również w pokryciu terenu przez gatunki charakterystyczne dla olsów (lasów 
bagiennych - Ol). Po trzech latach oddziaływania tamy bobrowej nastapił ośmiokrotny wzrost przeciętnego procentowego pokrycia gatunków olsowych na kwadratach próbnych. Gatunki charakterystyczne dla eutroficznych lasów łęgowych zmniejszyły swój udział na powierzchniach próbnych średnio o połowę - z 20,6 do $10,6 \%$.

Podsumowując należy stwierdzić, że obecność i aktywność bobrów w środowisku olsów jesionowych ma znaczenie pozytywne. Powstanie rozlewisk w ciagu ostatnich 3 lat spowodowało restytucję zespołu potencjalnego Circaeo-Alnetum ranunculetosum. Badany płat przesuszonego siedliska olsu jesionowego uległ naturalnej restytucji. Behawioralne właściwości bobrów mogą być jednak postrzegane jako niekorzystne z punktu widzenia gospodarki leśnej, gdyż w miejscu spiętrzeń następuje obumieranie drzewostanu. Dlatego końcowa ocena aktywności bobrów w środowisku leśnym może bardzo od siebie odbiegać, zależnie od sposobu potraktowania tego problemu.

Reviewers:

MSc Anna Matysiak

Dr. Kinga Pachuta 